\title{
HUBUNGAN ANTARA DUKUNGAN IBU DENGAN KECEMASAN MENGHADAPI MENARCHE (MENSTRUASI PERTAMA) PADA ANAK MASA PRAPUBERTAS
}

\author{
Tarwina Anggraini ${ }^{1}$, Triana Noor Edwina ${ }^{2}$ \\ ${ }^{12}$ Universitas Mercu Buana Yogyakarta \\ 2winasoeharto@gmail.com
}

\begin{abstract}
Abstrak
Penelitian ini bertujuan untuk mengetahui hubungan antara dukungan ibu dengan kecemasan menghadapi menarche (menstruas1 pertama) pada anak masa prapubertas. Hipotesis yang diajukan adalah ada hubungan negatif antara dukungan ibu dengan kecemasan menghadapi menarche (menstruasi pertama) pada anak masa prapubertas. Subjek dalam penelitian ini adalah anak perempuan yang memasuki masa prapubertas pada usia 10-12 tahun dan yang belum mengalami menstruasi pertama (menarche) di SD 2 Sungapan dengan jumlah subjek sebanyak 37 orang. Metode pengumpulan data yang digunakan adalah skala dukungan ibu dan skala kecemasan menghadapi menarche (menstruasi pertama) pada anak masa prapubertas. Hasil pengujian hipotesis dengan menggunakan teknik analisis korelasi Product Moment dari Pearson diperoleh hasil $\mathrm{r}=-0,386, \mathrm{p}<0,01$. Koefisien determinan yang diperoleh sebesar 0,149, artinya dukungan ibu memberikan sumbangan sebesar 14,9 $\%$ terhadap kecemasan menghadapi menarche (menstruasi pertama) pada anak masa prapubertas. Hal ini sekaligus menegaskan pengaruh variabel lain yang tidak diteliti dalam penelitian ini sebesar $85,1 \%$. Dengan demikian terdapat hubungan negatif antara dukungan ibu dengan kecemasan menghadapi menarche (menstruasi pertama) pada anak masa prapubertas. Hal ini menunjukkan bahwa hipotesis penelitian ini dapat diterima.
\end{abstract}

Kata kunci : dukungan ibu, kecemasan menghadapi menarche (menstruasi pertama) pada anak masa prapubertas

\section{THE RELATIONSHIP BETWEEN MOTHERS' SUPPORT AND ANXIETY IN FACING MENARCHE (FIRST MENSTRUATION) IN PRE-PUBERTAL CHILDREN}

\author{
Tarwina Anggraini ${ }^{1}$, Triana Noor Edwina ${ }^{2}$ \\ ${ }^{12}$ Universitas Mercu Buana Yogyakarta \\ 2winasoeharto@gmail.com
}

\begin{abstract}
This study aims to determine the relationship between a mother's support and anxiety in facing menarche (first menstruation) in pre-pubertal children. The hypothesis proposed is that there is a negative relationship between maternal support and anxiety in dealing with menarche (first menstruation) in prepubertal children. The subjects in this study were girls who entered the pre-pubertal period, at the age of 10-12 years and who had not experienced the first menstruation (menarche) at SD 2 Sungapan with a total subject of 37 persons. The data collection method used is the scale of maternal support and the scale of anxiety in facing menarche (first menstruation) in pre-pubertal children. The results of hypothesis testing using the Product Moment correlation analysis technique from Pearson obtained results $r=-0,386, p<0.01$. The determinant coefficient obtained was 0.149 , which means that mothers' support contributed $14.9 \%$ to anxiety in facing menarche (first menstruation) in pre-pubertal children. This also confirms the influence of other variables not examined in this study, as much as $85.1 \%$. Thus, there is a negative relationship between mothers' support and anxiety in facing menarche (first menstruation) in pre-pubertal children. This shows that the research hypothesis is acceptable.
\end{abstract}

Keywords: mother's support, anxiety in dealing with menarche (first menstruation) in pre-pubertal children 


\section{PENDAHULUAN}

Salah satu tahap perkembangan manusia adalah masa remaja. Darvil \& powell (2011) menyatakan bahwa masa remaja adalah masa transisi atau peralihan dari masa anak-anak ke masa dewasa. Calon (dalam Monk dkk, 1998) menjelaskan bahwa remaja belum memperoleh status orang dewasa tetapi tidak lagi memiliki status kanak-kanak. Permulaan masa remaja ditandai dengan perubahan-perubahan fisik dan psikis. Perubahan fisik antara lain perubahan berat badan, dan tubuh bertambah gemuk, adapun perubahan psikis diantaranya suasana hati yang selalu berubah-ubah, gejala emosi yang berlebihan dan gelisah. Pada saat itu mereka mulai melepaskan diri dari ikatan emosional dengan orang tuanya, pembentukan rencana hidup, dan sistem nilai sendiri (Gunarsa \& Gunarsa, 1991).

Perubahan fisik dan psikis yang dialami remaja mendahului kematangan seksualnya (Gunarsa \& Gunarsa, 1991). Menurut Chaplin (2000) periode dalam kehidupan saat kematangan organ-organ seks telah mencapai tahap fungsional disebut dengan pubertas (bahasa inggris puberty) atau dalam bahasa latin Pubescere berarti masa pertumbuhan rambut di daerah tulang public (di wilayah kemaluan), menandai masa akhir kanak-kanak dan awal dari masa remaja.

Menurut Kartono (1990) masa awal pubertas, disebut pula sebagai masa pueral atau masa prapubertas. Perubahan dari masa kanakkanak menuju masa remaja atau sering dikenal dengan istilah masa pubertas ditandai dengan datangnya haid pertama (menarche) pada wanita atau mimpi basah pada pria. Pubertas pada perempuan berlangsung lebih kompleks, ini dapat dilihat dari beragamnya usia ketika mendapat haid pertama. Haid pertama (menarche) merupakan menstruasi pertama yang biasa terjadi dalam rentang usia 10-16 tahun atau pada masa awal remaja di tengah masa pubertas sebelum memasuki masa reproduksi (Proverawati \& Misaroh, 2009).

Setiap perempuan pasti akan mengalami menarche (haid pertama). Kebiasaaan rutin itu akan terus berlangsung setiap bulan sehingga disebut datang bulan atau tamu bulanan. Haid pertama (menurut Lestari, 2011) merupakan salah satu perubahan pubertas yang pasti dialami setiap perempuan. Haid pertama merupakan proses fisiologis yang normal sehingga tidak perlu digelisahkan. Haid pertama juga menjadi tanda bahwa siklus masa subur telah dimulai. Haid pertama terjadi karena tubuh mulai memproduksi hormon-hormon seks yaitu progesteron dan estrogen yang membuat alat reproduksi anak perempuan bekerja dan membuat tubuh mengalami perubahan (Sahabat Remaja, 1998).

Menurut Lestari (2011) setelah perempuan mengalami haid pertama, peristiwa itu akan menjadi peristiwa rutin di setiap bulannya. Dengan demikian, mau atau tidak perempuan harus membiasakan kedatangan tamu bulanan tersebut dengan sikap yang wajar dan sehat agar tidak terjadi gangguan siklus haid sehingga berdampak pada gangguan kesuburan. Menstruasi adalah masalah normal yang akan, sedang, atau telah dialami setiap perempuan normal, tetapi sering terdengar keluhan tentang hal itu. Peristiwa itu tidak akan 
menjadi keluhan jika perempuan mengerti tentang apa itu menstruasi (Andrianto, 1993).

Kartono (1989) menjelaskan lebih lanjut bahwa gejala yang sering terjadi dan sangat mencolok pada peristiwa menstruasi pertama (menarche) ialah kecemasan atau ketakutan yang diperkuat oleh keinginan untuk menolak proses fisiologis. Kadang-kadang pada saat itu timbul pula sikap menyalahkan ibu yang telah melahirkannya sebagai perempuan yang harus mengalami siklus menstruasi setiap bulan. Timbul rasa bersalah dan berdosa, serta fantasifantasi yang tidak riil mengenai proses menstruasi, dan menganggap peristiwa menstruasi sebagai satu bencana. Pada banyak peristiwa, menstruasi pertama dihayati oleh anak perempuan sebagai pengalaman traumatis.

Istilah kecemasan dipakai untuk menunjukkan suatu respon emosional yang tidak menyenangkan dalam derajat yang berlebihan (Priest, 1994). Kecemasan merupakan salah satu gangguan psikologis ringan, yang ditandai dengan sifat obyek penyebab kecemasan itu tidak jelas, samarsamar, dapat menimbulkan rasa takut, was-was dan khawatir terhadap apa yang akan terjadi di masa depan. Kecemasan didefinisikan sebagai kondisi emosi tidak menyenangkan, obyeknya tidak jelas dan berkaitan dengan masa depan, memiliki karakteristik berupa munculnya perasaan takut, kehati-hatian atau kewaspadaan tidak jelas dan tidak menyenangkan (Fausiah \& Widuri, 2005).

Menurut Ibrahim (2007), kecemasan adalah sinyal yang menyadarkan seseorang untuk memperingatkan adanya bahaya yang mengancam dan memungkinkan seseorang mengambil tindakan guna mengatasi ancaman. Taufiq (1999) menambahkan bahwa kecemasan adalah emosi yang tidak menyenangkan, yang ditandai dengan istilah-istilah seperti "kekhawatiran," "keprihatinan," dan "rasa takut," yang kadang-kadang kita alami dalam tingkat yang berbeda-beda. Kecemasan menghadapi menarche (menstruasi pertama) pada anak masa prapubertas adalah perasaan yang tidak menyenangkan ditandai dengan istilah-istilah seperti "kekhawatiran," "keprihatinan," dan "rasa takut," yang kadangkadang kita alami dalam tingkat yang berbedabeda, yang terjadi pada anak perempuan saat menghadapi haid pertama atau datang bulan yang pertama kali pada masa akhir anak-anak sampai permulaan masa remaja. Kecemasan memiliki gejala, yang dibagi atas komponen fisik meliputi pusing, sakit perut, tangan berkeringat, perut mual, grogi dan lain-lain; komponen emosional seperti panik dan takut; komponen mental atau kognitif seperti gangguan perhatian dan memori, kekhawatiran dalam berpikir, dan bingung (Shah dalam Ghufron \& Risnawita, 2010).

Individu yang cemas atau takut saat menghadapi menarche, sama saja menyalahi fitrahnya sebagai manusia dan hanya mendatangkan kesengsaraan. Kesengsaraan ini dapat menghambat potensi, membuang tenaga, dan mengeruhkan kehidupan. Artinya, takut dan cemas akan datangnya menarche hanya menimbulkan kegelisahan (Faqih, 2003). Berdasarkan penjelasan di atas, anak pada masa prapubertas yang merasa cemas menghadapi menarche yang semakin dekat hanya akan menambah kesengsaraan pada anak. Kecemasan 
anak yang berlebihan pada saat menghadapi menarche (menstruasi pertama) akan berdampak pada belajar anak yang menjadi terganggu karena membayangkan menstruasi yang semakin dekat, kehilangan gairah dalam mengerjakan tugas, dan anak tidak dapat tidur dengan tenang karena takut menstruasi datang tiba-tiba. Hal senada juga dikatakan oleh Supratiknya (1995) mengatakan, manifestasi kecemasan adalah senantiasa diliputi ketegangan, rasa was-was yang berlebihan, mudah tersinggung, sulit berkonsentrasi dalam mengambil keputusan, sering buang air kecil, mengalami gangguan tidur, jantung berdebardebar, gangguang mimpi buruk.

Berbagai reaksi kecemasan dapat menghambat usaha individu untuk dapat mengekspresikan dirinya secara utuh serta dalam menjalankan tugas dan perannya secara maksimal (Subandi, 1998). Kecemasan dalam kadar yang rendah dapat berperan membantu individu untuk selalu siaga dalam mengambil langkah-langkah pencegahan bahaya atau untuk memperkecil kadar bahaya. Namun apabila kecemasan yang dialami sangat besar, justru akan menghambat individu tersebut dalam melakukan aktivitas, menjalin hubungan dengan orang lain serta mengembangkan diri (Fausiah \& Widury, 2005). Pada tingkat lanjut kecemasan dapat berakibat negatif dan merugikan, yaitu individu menjadi putus asa, tidak berdaya bahkan berusaha melarikan diri dari kenyataan yang sedang dihadapi (Prawitasari, 1988).

Burgoon \& Ruffner (1997) menyatakan bahwa kecemasan dianggap normal jika dapat membuat seseorang melakukan usaha terbaik untuk mencapai hasil yang maksimal, sebaliknya kecemasan yang berlebihan dapat menghambat seseorang untuk menunjukkan kapasitasnya. Suatu penelitian yang dilakukan oleh Conger (dalam Sriwindari, 2002), bahwa reaksi emosi terhadap menstruasi pertama pada 475 remaja putri adalah merasa biasa saja, sebagian merasa cemas, dan beberapa diantaranya merasa takut. Hanya $10 \%$ dari mereka yang menerima menarche dengan perasaan antusias, penasaran dan bangga. Hasil penelitian ini menunjukkan hampir sebagian anak perempuan memberikan respon negatif terhadap menarche (menstruasi pertama).

Melihat berbagai fenomena di atas, diharapkan anak yang belum siap dengan datangnya menarche, dapat mempersiapkan diri mereka menghadapi menarche. Reaksi perempuan terhadap menstruasi berbeda-beda, tergantung pada persiapannya menghadapi menstruasi pertama, serta respon-respon emosional terhadap kejadian tersebut (Landis dkk. Dalam Hamalik, 1995). Anak perempuan dikatakan siap apabila mampu menerima peristiwa menarche serta berbagai perubahan fisik yang menyertainya sebagai hal yang wajar dan akan dialami setiap perempuan normal. Anak perempuan yang tidak siap, menganggap peristiwa menarche sebagai sesuatu yang tidak menyenangkan, menimbulkan perasaan tidak nyaman, tidak berdaya, menakutkan, traumatis dan berusaha untuk menghindarinya sehingga anak menjadi cemas ketika menghadapi menarche.

Semua anak perempuan hampir bisa dipastikan pernah mengalami rasa cemas, gelisah, khawatir dan panik yang disebabkan 
ketika menghadapi menarche. Kecemasan pada setiap invidu berbeda, ada yang ringan, sedang dan ada yang berat, sehingga membutuhkan upaya penanganan untuk mengatasi kecemasan yang dialami. Rasa cemas adalah bagian dari emosi normal manusia. Kecemasan akan menjadi masalah pada anak ketika menghadapi menarche yang dialami bila berkepanjangan (Scholten, 2006).

Berdasarkan hasil wawancara pada tanggal 22 April 2014 di Kemusuk pukul 15.30 yang telah dilakukan peneliti dengan anak perempuan berinisial Hn berusia 9 tahun yang belum mengalami menarche (menstruasi pertama), peneliti menanyakan tentang perasaan anak tentang menarche (menstruasi pertama) yang semakin dekat. Anak mengatakan bahwa anak takut pada saat akan mengalami menstruasi karena anak masih bingung mengenai bagaimana cara memakai pembalut, apa saja yang akan dilakukan saat menstruasi datang. Gejala yang tampak pada anak di atas menunjukkan adanya gejala kecemasan. Gejala disini berupa gejala kecemasan emosional seperti takut dan gejala kecemasan mental/kognitif seperti bingung menurut Shah (dalam Ghufron \& Risnawita, 2010).

Ditambah hasil wawancara pada tanggal 30 dan 31 Desember 2014 di Kota Gede Yogyakarta pukul 14.00-selesai yang telah dilakukan dengan melibatkan 10 anak perempuan yang belum mengalami menarche (menstruasi pertama). Dari ke 10 anak perempuan, 8 anak mengungkapkan bahwa anak takut pada saat akan mengalami menstruasi karena anak takut melihat darah dan anak masih bingung mengenai bagaimana cara memakai pembalut, apa saja yang akan dilakukan saat menstruasi datang. Gejala yang tampak pada anak di atas menunjukkan adanya gejala kecemasan. Gejala disini berupa gejala kecemasan emosional seperti takut dan gejala kecemasan mental/kognitif seperti bingung menurut Shah (dalam Ghufron \& Risnawita, 2010). Dari 8 anak, 2 anak menjawab bahwa mereka merasa mual dan pusing jika melihat darah misalnya melihat bercak darah di rok temannya yang sudah menstruasi. Gejala yang tampak pada anak di atas menunjukkan adanya gejala kecemasan. Gejala disini berupa gejala kecemasan mental/kognitif seperti bingung menurut Shah (dalam Ghufron \& Risnawita, 2010). Dari hasil wawancara di atas, peneliti mengasumsikan bahwa ada indikasi kecemasan yang dirasakan anak dalam menghadapi menarche (menstruasi pertama). Anak merasa cemas manakala anak membayangkan dan memikirkan tentang menstruasi datang.

Ditambah hasil wawancara pada tanggal 5 September 2015 di SD 2 Sungapan, Bakal Dukuh, Argodadi, Sedayu, Bantul, Yogyakarta pukul 09.00-selesai yang telah dilakukan peneliti dengan 3 anak perempuan yang belum mengalami menarche (menstruasi pertama). Dari ke 3 anak disini mengungkapkan bahwa anak takut jika tiba-tiba menstruasi datang, anak juga takut melihat bercak darah di celana dalam, dan bingung jika mengalami menstruasi tibatiba, apa yang harus anak lakukan pada saat itu. Gejala yang tampak pada anak di atas menunjukkan adanya gejala kecemasan. Gejala disini berupa gejala kecemasan emosional seperti takut dan gejala kecemasan 
mental/kognitif seperti bingung menurut Shah (dalam Ghufron \& Risnawita, 2010).

Kecemasan menghadapi menarche (menstruasi pertama) pada anak merupakan implementasi dari rasa takut dan khawatir yang dialami anak mengenai hal yang baru yang ditemuinya. Apa yang ditemui dalam kenyataan tidak sesuai dengan apa yang ada dalam pikiran. Sesuai dengan tahap perkembangannya, anak memiliki kecenderungan untuk lebih ekspresif dalam mengeluarkan reaksi-reaksi kecemasan yang terjadi pada dirinya, sehingga kecemasan yang terjadi pada anak mudah terlihat oleh orang lain (Wenar, 1994).

Kecemasan menghadapi menarche (menstruasi pertama) adalah perasaan yang dialami anak perempuan sebagai respon subjektif berkaitan dengan peristiwa menarche (menstruasi pertama) yang menimbulkan perasaan tidak nyaman seperti gelisah, bingung, khawatir, dan takut sehingga anak merasa tidak berdaya dan berusaha untuk menghindarinya (Priest, 1994). Secara umum, faktor penyebab kecemasan menghadapi menarche (menstruasi pertama) pada anak masa prapubertas antara lain dukungan ibu (Nilawati dkk, 2013), pengetahuan tentang menarche (menstruasi pertama) (Yolanda dkk, 2013), dan sikap terhadap menstruasi (Ninawati \& Kuryadi, 2006). Diantara ketiga faktor penyebab kecemasan menghadapi menarche (menstruasi pertama) masa anak masa prapubertas seperti diuraikan di atas, penelitian ini hanya menitikberatkan pada faktor dukungan ibu. Ibu merupakan figur yang dekat dengan anak perempuannya dan pernah mengalami hal yang sama (Lestari, 2011).
Monks, dkk (2002) menyatakan bahwa kualitas hubungan antara seseorang dengan orang lain memegang peranan penting, misalnya hubungan antara ibu dengan anaknya. Adanya dukungan dan interaksi yang kooperatif antara ibu dengan anak pada masa remaja akan menimbulkan kedekatan. Seorang ibu biasanya memiliki sikap yang lebih menerima, lebih mengerti dan lebih kooperatif terhadap anak perempuannya dibandingkan ayah. Hal ini diperkuat dari penelitian Nilawati dkk (2013) dimana sebagian besar dukungan ibu terhadap anak menghadapi menarche dalam kategori mendukung $(62,2 \%)$ dan kecemasan anak menghadapi menarche dalam kategori sedang $(56,8 \%)$ dengan koefisien korelasi - 0,456 dan taraf signifikansi $0,005(\mathrm{p}<0,01)$. Dengan begitu ada hubungan antara dukungan ibu dengan kecemasan remaja dalam menghadapi menarche.

Menurut Margatan (1992) orang tua (khususnya ibu) diharapkan memberikan informasi yang tepat dan benar tentang apakah menstruasi itu. Mengetahui informasi yang benar tentang menstruasi maka anak perempuan akan merasa siap ketika mendapatkan menstruasi pertama kali. Selain itu anak perempuan dapat mengetahui hal apa saja yang harus dilakukan pada saat mengalami kondisi tersebut. Misalnya bagaimana mengatasi keluarnya darah menarche yang dapat terjadi sewaktu-waktu, bagaimana cara memakai dan mencuci pembalut, serta bagaimana perawatan diri pada saat menstruasi. Ketiadaan dukungan ibu akan dapat menimbulkan kecemasan pada anak perempuan ketika menghadapi menarche. 
Ibu merupakan sumber dukungan sosial yang berperan dalam pengasuhan anak, sehingga ibu perlu memberikan dukungan sosial kepada anaknya agar anak mampu berkembang dengan baik. Dukungan sosial yang diberikan ibu dapat memberikan manfaat positif bagi anak, karena menurut Gottlieb (Smet, 1994) dukungan sosial adalah informasi atau nasehat verbal atau non verbal, bantuan nyata atau tindakan yang diberikan oleh keakraban sosial atau di dapat karena kehadiran orang lain dan mempunyai manfaat emosional atau efek perilaku bagi pihak penerima.

Sarason dkk (1983) mendefinisikan bahwa dukungan sosial sebagai suatu keadaan yang bermanfaat bagi individu yang diperoleh dari individu lain yang dapat dipercaya dengan demikian individu menjadi tahu bahwa orang lain memperhatikan, menghargai, dan mencintai dirinya. Dukungan ibu adalah dukungan yang diberikan ibu kepada anak mencakup bantuan yang berupa perhatian, motivasi, pengarahan, dan memberikan semangat sehingga pihak penerima yaitu anak merasa diperhatikan saat mengalami kecemasan menghadapi menarche (menstruasi pertama).

House (dalam Smet, 1994) menjabarkan empat aspek dukungan sosial dipakai untuk menjelaskan aspek-aspek dukungan ibu, yaitu: dukungan emosional yaitu ungkapan empati, kepedulian, dan perhatian ibu terhadap orang yang bersangkutan yaitu anak. Dukungan penghargaan berupa ungkapan hormat (penghargaan) positif untuk anak, dorongan maju atau persetujuan dengan gagasan atau perasaan individu, dan perbandingan positif ibu dengan anak. Dukungan instrumental yaitu bantuan langsung yang diberikan ibu kepada anaknya. Dari dukungan instrumental akan muncul dukungan informatif yang berupa nasehat, petunjuk-petunjuk, saran-saran atau umpan balik, misalnya ibu membelikan majalah dan buku mengenai menstruasi, selanjutnya yang ibu lakukan adalah membaca buku tersebut lalu menjelaskannya kepada anak, agar anak mengetahui apa saja tanda-tanda saat mengalami menarche, cara mencuci pembalut, berapa kali sehari ganti pembalut.

Dukungan ibu diartikan sebagai sikap ataupun perbuatan yang ditunjukkan oleh orangorang terdekat yang memiliki hubungan kerabat atau pertalian darah terhadap anggota keluarga yang lainnya sebagai bantuan yang bersifat psikologis maupun fisik yang mampu membantu seseorang menyelesaikan masalah yang dihadapinya (Sarafino, 1998). Adanya peran ibu dalam memberikan dukungan tentang menarche (menstruasi pertama) secara dini setidaknya dapat memberikan pengaruh yang baik pada anak perempuannya guna mengurangi rasa cemas saat mereka memasuki masa menarche (menstruasi pertama). Oleh karena itu, dengan dukungan yang diberikan ibu kepada anak perempuannya diharapkan dapat memberikan pemahaman mereka secara dini tentang menarche (menstruasi pertama).

Disini dukungan yang diberikan ibu berupa dukungan emosional, penghargaan, instrumental dan informatif dibutuhkan dalam memberikan penjelasan kepada anaknya tentang kondisi yang akan dialaminya. Dukungan yang diberikan ibu terhadap anak perempuannya akan mempengaruhi kecemasan anak. Jika anak perempuan mendapatkan dukungan dari ibu 
pada saat menghadapi menarche (menstruasi pertama), anak akan siap dan percaya diri dalam menghadapi menarche (menstruasi pertama).

Apabila anak meyadari bahwa hal-hal yang tidak bisa berjalan dengan baik atau tidak sesuai dengan apa yang diharapkan, maka akan muncul gejala kecemasan. Gejala disini dapat berupa gejala kecemasan fisik, emosional, mental/kognitif menurut Shah (dalam Ghufron \& Risnawita, 2010). Perasaan cemas anak saat menghadapi menarche dapat dikurangi dengan adanya dukungan ibu. Anak dengan adanya peran ibu pada saat menghadapi menarche akan lebih siap menghadapi menarche. Apabila ibu menciptakan hubungan hangat dengan anaknya, anak akan lebih siap dan percaya diri dalam menghadapi menarche. Berdasarkan dinamika yang telah diuraikan di atas, dapat disimpulkan bahwa dukungan sosial dari ibu, dapat mengurangi kecemasan anak dalam menghadapi menarche. Dukungan ibu yang diberikan kepada anak mempunyai pengaruh sangat kuat bagi orang yang menerimanya, khususnya bagi anak yang akan mengalami menarche yang dapat membantu anak dalam menghadapi menarche.

Berdasarkan latar belakang masalah yang ada, dapat dirumuskan suatu masalah penelitian "Adakah hubungan antara dukungan ibu dengan kecemasan menghadapi menarche pada anak masa prapubertas?

Penelitian ini bertujuan untuk mengetahui hubungan antara dukungan ibu dengan kecemasan menghadapi menarche (menstruasi pertama) pada anak masa prapubertas.

Secara teoritis dalam penelitian ini diharapkan dapat memberikan masukan dalam penelitian dibidang psikologi klinis tentang hubungan antara dukungan ibu dengan kecemasan menghadapi menarche (menstruasi pertama) pada anak masa prapubertas, sehingga dapat dijadikan landasan bagi penelitianpenelitian lebih lanjut.

Secara praktis, jika penelitian ini terbukti diharapkan dapat memberikan gambaran dan masukan kepada orang tua terutama ibu tentang pemberian dukungan kepada anak pada masa prapubertas agar dapat mengurangi kecemasan menghadapi menarche (menstruasi pertama) dan kepada anak perempuan agar mereka bisa mempersiapkan diri mereka sebelum mengalami menarche (menstruasi pertama).

Secara praktis, jika penelitian ini tidak terbukti, maka anak perlu mencari referensi/pengetahuan tentang menghadapi menarche (menstruasi pertama) dan mempunyai sikap positif terhadap menarche (menstruasi pertama).

Kecemasan menurut Ibrahim (2007) adalah sinyal yang menyadarkan seseorang untuk memperingatkan adanya bahaya yang mengancam dan memungkinkan seseorang mengambil tindakan guna mengatasi ancaman. Taufiq (1999) menambahkan bahwa kecemasan adalah emosi yang tidak menyenangkan, yang ditandai dengan istilah-istilah seperti "kekhawatiran," "keprihatinan," dan "rasa takut," yang kadang-kadang kita alami dalam tingkat yang berbeda-beda. Kecemasan menghadapi menarche (menstruasi pertama) pada anak masa prapubertas adalah kondisi perasaan yang tidak menyenangkan yang terjadi pada masa akhir anak-anak sampai permulaan 
masa remaja saat mengalami menstruasi pertama kali.

Kecemasan memiliki gejala, yang dibagi atas komponen fisik meliputi pusing, sakit perut, tangan berkeringat, perut mual, grogi dan lain-lain; komponen emosional seperti panik dan takut; komponen mental atau kognitif seperti gangguan perhatian dan memori, kekhawatiran dalam berpikir, dan bingung menurut Shah (dalam Ghufron \& Risnawita, 2010).

Secara umum faktor penyebab kecemasan menghadapi menarche (menstruasi pertama) pada anak masa prapubertas antara lain dukungan ibu (Nilawati, dkk, 2013), pengetahuan tentang menarche (menstruasi pertama) (Yolanda, dkk, 2013), dan sikap terhadap menstruasi (Ninawati \& Kuryadi, 2006). Diantara ketiga faktor penyebab kecemasan menghadapi menarche (menstruasi pertama) masa anak masa prapubertas seperti diuraikan diatas, penelitian ini hanya menitikberatkan pada faktor dukungan ibu. Hal tersebut diambil dengan pertimbangan bahwa ibu merupakan figur yang dekat dengan anak perempuannya dan pernah mengalami hal yang sama. Hal ini diperkuat oleh Nilawati, dkk (2013) yang menyatakan bahwa dukungan sosial yang diberikan ibu terhadap kecemasan remaja putri dalam menghadapi menarche (mentruasi pertama) dapat memberikan keuntungan emosional dan berpengaruh terhadap tingkah laku penerimanya yaitu anak. Dalam hal ini orang yang merasa memperoleh dukungan sosial, emosional merasa lega karena diperhatikan, mendapat saran atau kesan yang menyenangkan pada dirinya.
Gottlieb (Smet, 1994) menyatakan bahwa dukungan sosial adalah informasi atau nasehat verbal atau non verbal, bantuan nyata atau tindakan yang diberikan oleh keakraban sosial atau di dapat karena kehadiran orang lain dan mempunyai manfaat emosional atau efek perilaku bagi pihak penerima. Rook (dalam Smet, 1994) mengaganggap dukungan sosial sebagai salah satu fungsi pertalian sosial. Dukungan ibu merupakan salah satu bagian dari dukungan sosial. House (dalam Smet, 1994) mencoba mengintegrasikan dukungan ibu sebagai transaksi interpersonal yang melibatkan : dukungan Emosional (ungkapan empati, kepedulian, dan perhatian), dukungan Penghargaan (ungkapan hormat (penghargaan) positif untuk seseorang, dorongan maju atau persetujuan dengan gagasan atau perasaan individu, dan perbandingan positif orang tersebut dengan orang lain), dukungan Instrumental (bantuan langsung), dan dukungan Informatif (nasehat, petunjuk-petunjuk, saransaran atau umpan balik). Jika dukungan yang diberikan oleh ibu meningkat maka kecemasan remaja dalam menghadapi menarche (menstruasi pertama) akan menurun. Sebaliknya jika dukungan ibu kurang maka kecemasan remaja dalam menghadapi menarche (menstruasi pertama) akan meningkat (Nilawati, dkk, 2013).

Monks, dkk (dalam Ashriati, 2006), mengatakan bahwa kualitas hubungan antara orang tua terutama ibu dengan anak memegang peranan penting. Adanya dukungan dan interaksi yang kooperatif antara ibu dengan anak pada masa remaja akan menimbulkan kedekatan. Seorang ibu biasanya memiliki sikap 
yang lebih menerima, lebih mengerti dan lebih kooperatif terhadap anak perempuannya dibandingkan ayah. Dengan adanya peran ibu dalam memberikan dukungan serta informasi tentang menarche (menstruasi pertama) secara dini setidaknya dapat memberikan pengaruh yang baik pada anak perempuannya guna mengurangi rasa cemas saat mereka memasuki masa menarche (menstruasi pertama). Oleh karena itu, dengan dukungan yang diberikan ibu kepada anak perempuannya diharapkan dapat memberikan pemahaman mereka secara dini tentang menarche (menstruasi pertama).

Disini dukungan yang diberikan ibu dibutuhkan. Ibu akan memberikan penjelasan kepada anaknya tentang kondisi yang akan dialaminya. Apabila anak menyadari bahwa halhal yang tidak bisa berjalan dengan baik atau tidak seseuai dengan yang diharapkan, maka anak akan merasa cemas. Dukungan yang diberikan ibu terhadap anak perempuannya akan mempengaruhi kecemasan anak. Jika anak perempuan mendapatkan dukungan dari ibu saat menghadapi menarche (menstruasi pertama), anak cenderung mempunyai kecemasan yang rendah, sedangkan anak perempuan yang tidak mendapatkan dukungan dari ibu cenderung mempunyai kecemasan yang tinggi saat menghadapi menarche (menstruasi pertama). Hal ini sesuai dengan pendapat Hurlock (2006) dimana untuk mengatasi kecemasan anak perempuan saat menghadapi menarche diperlukan adanya komunikasi, karena dengan komunikasi anak perempuan dapat mengutarakan kecemasannya kepada orang lain khususnya ibu mereka sehingga dapat memperoleh pandangan baru dan lebih baik.
Lestari (2011) mengemukakan dalam penelitian lain, remaja putri yang berusia 10-16 tahun dalam sebuah kelompok masyarakat, yang diberikan pertanyaan secara langsung seputar haid, 8 persen mengatakan belum mendapatkan informasi tentang haid secara lengkap dari orangtuanya, dan 2 persen sudah mendapatkan informasi tentang haid dari orangtuanya. Sebagian besar dari mereka mengatakan belum paham betul arti haid pertama karena ibunya tidak pernah memberikan informasi sebatas cara penggunaan pembalut dan kewajiban mandi menurut tuntunan agama sehingga remaja putri tersebut ketika mengalami haid merasa bingung dan tidak siap.

Hipotesis yang diajukan adalah ada hubungan negatif antara dukungan ibu dengan kecemasan menghadapi menarche (menstruasi pertama) pada anak masa prapubertas. Semakin tinggi dukungan ibu maka kecemasan menghadapi menarche (menstruasi pertama) pada anak masa prapubertas semakin rendah, sebaliknya semakin rendah dukungan ibu maka kecemasan menghadapi menarche (menstruasi pertama) pada anak masa prapubertas akan semakin tinggi.

\section{METODE}

Identitas variabel penelitian pada variabel tergantung adalah Kecemasan Menghadapi Menarche (Menstruasi Pertama) Pada Anak Masa Prapubertas, pada variabel bebas adalah dukungan ibu

Definisi operasional variabel pada kecemasan anak menghadapi menarche (menstruasi pertama) adalah kondisi perasaan 
yang mengancam tetapi merupakan hal yang normal untuk menemukan identitas diri yang dialami oleh anak perempuan sebagai tanda bahwa alat reproduksi anak telah berfungsi yang terjadi pada masa akhir anak-anak sampai permulaan masa remaja.

Skala yang digunakan adalah skala kecemasan menghadapi menarche (menstruasi pertama) pada anak masa prapubertas yang disusun oleh penulis mencakup gejala kecemasan dari Shah (dalam Ghufron \& Risnawita, 2010) yang meliputi : komponen fisik meliputi pusing, sakit perut, tangan berkeringat, perut mual, grogi dan lain-lain; komponen emosional seperti panik dan takut; komponen mental atau kognitif seperti gangguan perhatian dan memori, kekhawatiran dalam berpikir, dan bingung. Semakin tinggi skor yang diperoleh subjek maka semakin tinggi pula kecemasan menghadapi menarche (menstruasi pertama) pada anak masa prapubertas dan semakin rendah skor yang diperoleh subjek maka semakin rendah pula kecemasan menghadapi menarche (menstruasi pertama) pada anak masa prapubertas.

Definisi operasional variabel pada dukungan ibu adalah dukungan yang diberikan ibu kepada anak mencakup bantuan yang berupa perhatian, motivasi, pengarahan, dan memberikan semangat sehingga pihak penerima yaitu anak merasa diperhatikan saat mengalami kecemasan menghadapi menarche (menstruasi pertama). Dukungan ibu akan diukur menggunakan skala dukungan ibu yang disusun oleh penulis meliputi aspek - aspek dari House (dalam Smet, 1994) yaitu dukungan emosional, dukungan penghargaan, dukungan instrumental dan dukungan informatif. Semakin tinggi skor yang diperoleh subjek, maka semakin tinggi dukungan ibu, sedangkan semakin rendah skor yang diperoleh subjek, maka semakin rendah dukungan ibu.

Subjek penelitian ini adalah anak perempuan yang memasuki masa prapubertas pada usia 10-12 tahun dan yang belum mengalami menarche (menstruasi pertama) karena prapubertas adalah periode sekitar kurang lebih dua tahun sebelum terjadinya pemasakan seksual yang sesungguhnya tetapi sudah terjadi perkembangan fisiologis yang berhubungan dengan pemasakan beberapa kelenjar endokrin. Kelenjar endokrrin adalah kelenjar yang bermuara langsung di dalam saluran darah. Zat-zat yang di keluarkan disebut hormon.

Metode yang digunakan untuk mengumpulkan data dalam penelitian ini berupa skala model Guttman yang memuat dua pilihan jawaban yaitu berupa Ya (Y) dan Tidak (T). Skala yang digunakan :

1. Skala Kecemasan Menghadapi Menarche (Menstruasi Pertama) Pada Anak Masa Prapubertas

Skala kecemasan menghadapi menarche (menstruasi pertama) pada anak masa prapubertas yang digunakan berdasarkan tiga komponen kecemasan yang dikemukakan oleh Shah (dalam Ghufron \& Risnawita 2010) yaitu: Komponen fisik (pusing, sakit perut, tangan berkeringat, perut mual, grogi dan lain-lain), Komponen emosional (panik dan takut), Komponen mental atau kognitif (gangguan 
perhatian dan memori, kekhawatiran dalam berpikir, dan bingung).

Skala sebelum uji coba berisi 45 aitem. Terdapat 12 aitem yang gugur dan 33 aitem yang valid, sehingga skala layak digunakan untuk penelitian selanjutnya. Syarat agar suatu aitem layak dipakai jika berada diatas 0,20. Koefisien validitas aitem berkisar antara 0,237 sampai 0,663. Berdasarkan hasil penelitian menunjukkan koefisien reliabilitas sebesar 0,856 . Artinya hasil pengukuran skala tampak varians skor murni, yaitu memiliki kepercayaan sebesar $85,6 \%$.

\section{Skala Dukungan Ibu}

Skala dukungan ibu disusun oleh peneliti dengan menggunakan aspek dari House (dalam Smet, 1994) yaitu : dukungan emosional, dukungan penghargaan, dukungan instrumental, dukungan informatif.

Skala sebelum uji coba berisi 32 aitem terdapat 30 aitem valid dan 2 aitem yang gugur, sehingga skala ini layak digunakan untuk penelitian selanjutnya. Koefisien validitas aitem berkisar antara 0,203 sampai 0,648. Berdasarkan penelitian menunjukkan koefisien reliabilitas sebesar 0,875. Artinya hasil dari pengukuran skala tampak varians skor murni, yaitu memiliki kepercayaan sebesar 87,5\% .

Analisis data yang digunakan adalah korelasi product moment (r) dari person. Alasan untuk mengetahui hubungan antara dukungan ibu dengan kecemasan menghadapi menarche (menstruasi pertama) pada anak masa prapubertas. Penghitungan statistik menggunakan program analisis statistik. Sebelum pengujian hipotesis, dilakukan uji asumsi yaitu uji normalitas dan uji linieritas.
Uji coba skala dilakukan di SD 1 Dingkikan pada tanggal 26 Mei 2015 dengan jumlah anak 47 orang, terdapat 38 orang yang layak untuk dijadikan subjek penelitian, sebab 3 orang sudah mengalami menstruasi, dan 6 orang sudah berusia diatas 12 tahun. Sedangkan pelaksanaan penelitian dilakukan pada tanggal 6 Juni 2015 dilakukan di SD 2 Sungapan dengan jumlah 50 orang, terdapat 37 orang yang layak untuk dijadikan subjek penelitian, sebab 11 orang sudah mengalami menstruasi, dan 2 orang sudah berusia diatas 12 tahun sehingga tidak sesuai dengan ciri-ciri yang telah ditetapkan.

\section{Hasil Dan Diskusi}

Data yang diperoleh digunakan sebagai dasar pengujian hipotesis.

a. Skala kecemasan menghadapi menarche (menstruasi pertama) pada anak masa prapubertas

Berdasarkan perhitungan skor hipotetik kecemasan menghadapi menarche (menstruasi pertama) pada anak masa prapubertas, skor minimal sebesar 0 dan maksimal sebesar 33 . Rerata empiris sebesar 16,5 dan standar deviasinya $(\sigma)$ sebesar 5,5. Mean empirik 6,81 berada pada klasifikasi rendah, sedangkan mean hipotetik 16,5 tinggi. Data empirik kecemasan menghadapi menarche (menstruasi pertama) pada anak masa prapubertas lebih kecil daripada data hipotetik $(6,81<16,5)$. Subjek memiliki kecemasan menghadapi menarche (menstruasi pertama) pada anak masa prapubertas yang rendah.

b. Dukungan ibu

Berdasarkan perhitungan skor hipotetik dukungan ibu, skor minimal sebesar 0 dan maksimal sebesar 30. Rerata empiris sebesar 15 
dan standar deviasinya $(\sigma)$ sebesar 5. Mean empirik 17,84 berada pada klasifikasi tinggi, sedangkan mean hipotetik 15 rendah. Data empirik dukungan ibu lebih besar daripada data hipotetik $\quad(17,84<15)$. Subjek memiliki dukungan ibu yang tinggi.

Pengujian hipotesis menggunakan uji prasyarat dan uji korelasi. Uji prasyarat berupa uji normalitas dan linieritas. Uji normalitas sebaran dilakukan dengan menggunakan teknik Kolmogorov-Smirnov. Adapun hasil uji normalitas dari data kecemasan menghadapi menarche (menstruasi pertama) pada anak masa prapubertas menunjukkan nilai $\mathrm{KS}-\mathrm{Z}$ sebesar 0,121 dengan taraf signifikan 0,190 dengan $(p>$ 0,05). Hal tersebut menunjukkan bahwa variabel kecemasan menghadapi menarche (menstruasi pertama) pada anak masa prapubertas mempunyai sebaran normal. Hasil uji normalitas dari data dukungan ibu menunjukkan nilai KS-Z sebesar 0,133 dengan taraf signifikasi 0,095 dengan ( $\mathrm{p}>0,05)$. Hal tersebut menunjukkan bahwa variabel dukungan ibu mempunyai sebaran normal.

Hasil uji linieritas dalam penelitian ini menggunakan test of linearity. Berdasarkan perhitungan yang dilakukan, suatu data dikatakan linier apabila $\mathrm{p}<0,05$. Hasil uji linieritas kedua variabel menunjukkan koefisien linieritas (nilai F) sebesar sebesar 6,479 dengan taraf signifikan $0,018(\mathrm{p}<0,05)$. Hal tersebut berarti kedua variabel mempunyai hubungan yang linier.

Pada uji korelasi hasil analisis data menunjukkan koefisien korelasi $\mathrm{rxy}=-0,386$ dan taraf signifikansi $0,009 \quad(\mathrm{p}<0,01)$. Berdasarkan hasil tersebut berarti ada hubungan negatif yang signifikan antara dukungan ibu dengan kecemasan menghadapi menarche (menstruasi pertama) pada anak masa prapubertas sehingga hipotesis yang diajukan dalam penelitian ini diterima.

Hasil penelitian ini menunjukkan ada hubungan negatif antara dukungan ibu dengan kecemasan menghadapi menarche (menstruasi pertama) pada anak masa prapubertas. Hasil analisis penelitian ini membuktikan bahwa hipotesis yang menyatakan ada hubungan negatif antara dukungan ibu dengan kecemasan menghadapi menarche (menstruasi pertama) pada anak masa prapubertas diterima koefisien korelasi rxy $=-0,386(p<0,01)$.

Berdasatkan korelasi rxy $=-0,386 \quad(\mathrm{p}<$ $0,01)$ variabel dukungan ibu dengan kecemasan menghadapi menarche (menstruasi pertama) pada anak masa prapubertas diketahui bahwa dukungan ibu memberikan sumbangan sebesar $14,9 \%$ terhadap kecemasan menghadapi menarche (menstruasi pertama) pada anak masa prapubertas.

Dari hasil data penelitian yang dilakukan oleh peneliti menggunakan skala diperoleh bahwa sebagian besar ibu memberikan dukungan emosional, dukungan penghargaan, dukungan instrumental dan dukungan informatif kepada anaknya menjelang menarche (menstruasi pertama) yang berupa memahami perubahan emosi anak yang tidak stabil selama menjelang menstruasi, ibu memberi pujian kepada anak jika ia sudah mengalami kematangan seksual, ibu membelikan anak majalah atau buku-buku mengenai menstruasi, dan ibu juga menjelaskan tanda-tanda saat akan menstruasi, cara mencuci pembalut, berapa kali 
sehari ganti pembalut. Banyaknya ibu yang dikategorikan mendukung dikarenakan sebagian besar sudah mengetahui menstruasi dengan baik dan memiliki pengalaman yang tidak mudah dilupakan ketika mengalami mensrtuasi pertama (menarche).

Ketika anak merasa mendapatkan bantuan berupa perasaan dihargai, dihormati, mendapatkan kepedulian dari ibu, merasa tercukupi kebutuhannya, kesehatannya juga terjamin, akan merasa dirinya mendapat fasilitas dan informasi yang memadai dari ibu, sangat dimungkinkan ketegangan seperti kecemasan pada saat menghadapi menarche (menstruasi pertama) akan berkurang.

Dari hasil analisis data, menunjukkan koefisien determinan sebesar 0,149 yang berarti dukungan ibu memberikan sumbangan sebesar $14,9 \%$ terhadap kecemasan menghadapi menarche (menstruasi pertama) pada anak masa prapubertas. Dengan demikian peneliti berasumsi bahwa masih ada variabel lain yang mempengaruhi kecemasan menghadapi menarche (menstruasi pertama) pada anak masa prapubertas sebesar $85,1 \%$. Faktor-faktor lain yang mempengaruhi misalnya pengetahuan tentang Menarche (menstruasi pertama) (Yilanda dkk, 2013) dan sikap terhadap menstruasi (Ninawati dan Kuryadi, 2006).

Berdasarkan uraian diatas maka disimpulkan bahwa terdapat hubungan negatif antara dukungan ibu dengan kecemasan menghadapi menarche (menstruasi pertama) pada anak masa prapubertas menunjukkan bahwa semakin tinggi dukungan ibu, maka kecemasan menghadapi menarche (menstruasi pertama) pada anak masa prapubertas semakin rendah. Sebaliknya semakin rendah dukungan ibu, maka kecemasan menghadapi menarche (menstruasi pertama) pada anak masa prapubertas semakin tinggi.

\section{PENUTUP}

Berdasarkan uraian dapat disimpulkan bahwa hipotesis yang diajukan dapat diterima karena berdasarkan hasil analisis menyatakan bahwa ada hubungan negatif antara dukungan ibu dan kecemasan menghadapi menarche (menstruasi pertama) pada anak masa prapubertas ditunjukkan dengan koefisien korelasi - 0,386 ( $\mathrm{p}<0,01)$. Semakin tinggi dukungan ibu maka kecemasan menghadapi menarche (menstruasi pertama) pada anak masa prapubertas akan semakin rendah. Sebaliknya semakin rendah dukungan ibu maka kecemasan menghadapi menarche (menstruasi pertama) pada anak masa prapubertas akan semakin tinggi. Sumbangan efektif variabel dukungan ibu terhadap kecemasan menghadapi menarche (menstruasi pertama) pada anak masa prapubertas sebesar $14,9 \%$, artinya dukungan ibu hanya salah satu faktor yang dapat mengurangi kecemasan menghadapi menarche (menstruasi pertama) pada anak masa prapubertas sedangkan sisanya $85,1 \%$ dipengaruhi oleh faktor lain. Faktor - faktor lain tersebut adalah pengetahuan tentang menarche (mentruasi pertama) dan sikap terhadap menstruasi.

Berdasarkan hasil penelitian, pembahasan dan kesimpulan maka beberapa saran yang diajukan untuk peneliti selanjutnya antara lain :

1. Bagi Anak 
Anak diharapkan dapat mempertahankan kondisi yang sudah ada dengan cara memanfaatkan berbagai bentuk dukungan yang diberikan ibu, agar anak tidak mengalami kecemasan saat akan menghadapi menarche (menstruasi pertama).

2. Bagi Ibu

Hasil penelitian menunjukkan bahwa dukungan yang diberikan ibu sudah baik sehingga diharapkan para ibu tetap memberi perhatian kepada anaknya dengan memberikan berbagai dukungan terhadap anak, baik dalam bentuk dukungan emosional, penghargaan, instrumental, dan informatif yang dapat diwujudkan ibu dengan menciptakan suasana nyaman seperti pengertian, cinta, keakraban, motivasi, perhatian, rasa percaya, kepedulian kepada anak untuk bertanya mengenai menarche (menstruasi pertama) agar anak tidak mengalami kecemasan saat menghadapi menarche (menstruasi pertama).

3. Untuk Peneliti Selanjutnya

Peneliti ini menunjukkan bahwa dukungan ibu memberikan sumbangan sebesar $14,9 \%$ terhadap tinggi rendahnya kecemasan menghadapi menarche (menstruasi pertama) pada anak masa prapubertas. Oleh karena itu, bagi peneliti yang memiliki minat yang sama dalam meneliti kecemasan menghadapi menarche (menstruasi pertama) pada anak masa prapubertas disarankan untuk:

a. Mengkaji variabel-variabel lain yang dapat menjadi penyebab kecemasan menghadapi menarche (menstruasi pertama) pada anak masa prapubertas seperti pengetahuan tentang menarche (menstruasi pertama) dan sikap terhadap menstruasi.

b. Memperbaiki pernyataan yang ada di skala untuk mengungkap dukungan ibu dan kecemasan menghadapi menarche (menstruasi pertama) pada anak masa prapubertas agar lebih jelas aspek - aspek yang ingin diteliti.

c. Diharapkan dilakukan observasi dan wawancara pendahuluan memiliki karakteristik subjek yang sama, agar diperoleh gambaran tentang kecemasan menghadapi menarche (menstruasi pertama).

\section{DAFTAR PUSTAKA}

Andranto, P. (1993). Haid: Problem Wanita Dahulu, Kini dan Masa Depan. Jakarta: Arcan.

Ashriati, N., Alsa, A., \& Suprihatin, T. (2006). Hubungan Antara Dukungan Sosial Orang Tua Dengan Kepercayaan Diri Remaja Peyandang Cacat Fisik Pada SLB - D YPAC Semarang. Jurnal Psikologi Proyeksi, 1(1).

Azwar, S. (1997). Reliabilitas dan validitas. Yogyakarta: Pustaka Belajar.

Azwar, S. (1998). Sikap Manusia Teori dan Pengukurannya. Edisi ke-2. Yogyakarta: Pustaka Belajar.

Azwar, S. (2001). Metodologi Penelitian. Yogyakarta: Pustaka Pelajar.

Azwar, S. (2012). Metodologi Penelitian. Yogyakarta. Pustaka Pelajar.

Bataman, H.D. (1996). Meraih Hidup Bermakna. Jakarta: Paramadina.

Burgoon, M., \& Ruffner, M. (1997). Human Communication. a Revision of Approaching Speech/Communication. 
New York; Holt Rinehart and Winston inc.

Chaplin, P. J. (2000). Kamus Lengkap Psikologi. PT. Raja Grafindo Persada.

Darvill, W., \& Powell, K. (2001). The Puberty Book. Panduan Untuk Remaja. Alih Bahasa: Theresia Saputro. Jakarta: PT Gramedia Pustaka Utama.

Dolan, P., Canavan, J., \& Pinkerton, J. (2006). Family Support as Reflective Practice. London: Jessica Kingsley Publishers.

Durand, V.M., \& Baslow, D.H. (2006). Intisari Psikologi Abnormal. Yogyakarta: Pustaka Pelajar.

Fausiah, S., \& Widury, J. (2005). Psikologi Abnormal "Klinis Dewasa". Jakarta: Fakultas Psikologi Universitas Indonesia.

Fausiah, S., \& Widury, J. (2006). Psikologi Abnormal "Klinis Dewasa". Jakarta: Penerbit UI Press.

Faturocman. (2001). Revitalisasi Peran Keluarga. Buletin Psikologi, 9(2), 39-47.

Ghufron, M.N., \& Risnawita, R.S. (2010). Teori-Teori Psikologi. Cetakan I. Jogjakarta: Penerbit Ar-Ruzz Media.

Gunarsa, Y.S.D., \& Gunarsa, S.D. (1991). Psikologi Remaja. Jakarta: PT BPK Gunung Mulia.

Hadi, S. (1987). Metodologi Research. Yogyakarta: Rineka Cipta.

Hadi, S. (2001). Metodologi Research. Yogyakarta. Andi Yogyakarta.

Hamalik, O. (1995). Psikologi Remaja: Dimensi-Dimensi Perkembangan. Bandung: Maju Mundur.

Hawari, D. (2006). Manajemen Stres Cemas Dan Depresi. Edisi Ke-2. Jakarta: Penerbit FKUI.

Hurlock, E.B. (1980). Psikologi Perkembangan. Jakarta: Erlangga.
Hurlock, E. (2001). Psikologi Perkembangan. Edisi 5. Jakarta: Erlangga.

Hurlock. (2006). Suatu Pendekatan Sepanjang Rentang Kehidupan. Edisi V. Jakarta: Erlangga.

Ibrahim, A.S. (2007). Panik Neurosis Gangguan Cemas. Jakarta: Penerbit Dua As-As.

Johnson, D.W., \& Johnson, F. (1991). Joining Together. Group Theory and Group Skill. Fourth Edition. Englewood Cliffts. Prentice Hall Inc.

Johnson, D.W. (1993). Reaching Out: Interpersonal Effectiveness and Self Actualization. (5th ED). Boston: Allyn \& Bacon.

Kartono, K. (1989). Psikologi Wanita: mengenal Gadis Remaja dan Wanita Dewasa. Jilid 1. Bandung: PKBI.

Kartono, K. (1990). Psikologi Anak (Psikologi Perkembangan). Bandung: Mandar Maju.

Kumolohadi, R. (2001). Tingkat Stres Dosen UII ditinjau dari Dukungan Suami. Jurnal Pemikiran dan Penelitian Psikologi,12(6), 30-36.

Lestari, N. (2011). Tips Praktis Mengetahui Masa Subur. Jogjakarta: Katahati.

Maramis, W.F., \& Maramis, A.A. (2009). Catatan Ilmu Kedokteran Jiwa. Edisi Kedua. Surabaya: Airlangga University Press.

Margatan, A. (1992). Apa Yang Harus Anda Katakan pada Putera-puteri Anda tentang Menstruasi. Solo; CV Aneka.

Misaroh, S., \& Proverawati, A. (2009). Menarche. Yogyakarta: Penerbit Nuha Medika.

Monk, F.J., Knoers, A.M.P., \& Haditono, S.R. (1998). Psikologi Perkembangan. Yogyakarta: Gadjah Mada University Press. 
Monks, F.J., Knoers, A.M.P., \& Haditono, S.R. (2002). Psikologi Perkembangan : Pengantar Dalam Berbagai Bagiannya. Yogyakarta : Gajah Mada University Press.

Monk, F.J., Knoers, A.M.P., \& Haditono, S.R. (2006). Psikologi Perkembangan: Pengantar Dalam Berbagai Bagiannya. Yogyakarta: Gadjah Mada University Press.

Nilawati, I., Sumarni., \& Santjaka, A. (2013). Hubungan antara Dukungan Ibu Dengan Kecemasan Remaja Dalam Menghadapi Menarche Di SD Negeri Lomanis 01 Kecamatan Cilacap Tengah Kabupaten Cilacap. Jurnal Ilmiah Kebidanan, 4(1), 178-189.

Ninawati., \& Kuryadi, J. (2006). Hubungan Antara Sikap Terhadap Menstruasi Dan Kecemasan Terhadap Menarche. Jurnal Psikologi, 4(1), 38-54.

Oktavia, L., \& Basri, A.S. (2002). Hubungan Antara Dukungan Sosial yang Diterima Secara Nyata Dengan Ada atau Tidaknya Gangguan seperti Pasca Persalinan Pada Ibu Dewasa Muda. Jurnal Psikologi. Vol. $8(1), 26-38$.

Prawitasari, J. E. (1988). Stres dan Kecemasan: Pengertian, Manifestasi dan Penanganan. Kumpulan Makalah. Yogyakarta: Fakultas Kedokteran Universitas Gadjah Mada.

Perestroika, G.D., Agustin, R.W., \& Budi, C.E. (2011). Pengaruh Penyuluhan Menstruasi terhadap Kecemasan Menghadapi Menarche pada Remaja Putri Kelas VII SMP N 2 Punggelan Banjarnegara. Jurnal. Program Studi DIV Kebidanan Fakultas Kedokteran Universitas Sebelas Maret Surakarta. 5866.

Priest, G.Q. (1994). Student TeamsAchievement Divisions. (STAD) Applications to the Social Studies Classroom. A Handbook for Teacher.
Proverawati, A., \& Misaroh, S. (2009). Menarche:Menstruasi Pertama Penuh Makna. Yogyakarta: Nuha Medika.

Ramaiah, S. Dr. (2006). Mengatasi Gangguan Menstruasi. Jogjakarta : Book Marks Diglossia Media.

Sahabat Remaja. (1998). Buklet: Remaja dan Kesehatan Seksual. Yogyakarta: Sahaja PKBI DIY.

Sarason, I.G., Levine, H.M., Bashar, R.B \& Sarason, R.B. (1983). Assessing Social Sipport; The Social Support Quastionare. Journal of Personality and Social Psychology, 44(1-3), 127-139.

Sarafino, E.P. (1998). Health Psyhology: Biopsyholosocial Interaction. Third Edition. New York: John Wiley \& Sons Inc.

Smet, B. (1994). Psikologi Kesehatan. Jakarta: Grasindo.

Sriwindari, D. (2002). Hubungan Antara Pengetahuan Tentang Menstruasi Dengan Kecemasan Menghadapi Menarche Pada Remaja Putri Prapubertas. Universitas Muhamadiyah, Malang. Jurnal Psikodinamik, 4(2), 120-137.

Sulaeman. (1995). Psikologi Remaja. DimensiDimensi Perkembangan. Bandung: Maju Mundur.

Supratiknya, A. (1995). Mengenal Perilaku Abnormal. Jakarta: Kanisius.

Thoit, P. A. (1986). Social Support as Coping Assistance. Journal of Counsulting and Clinical Psychology, 54(4), 416-423.

Utami, S.M., \& Hasanat, U.N. 1998. Dukungan Sosial pada Penderita Kanker. Jurnal Psikologi, 25(1), 44-45.

Warsiki, E. (1988). Kecemasan Pada Anak dan Remaja: ANIMA Media Psikologi Indonesia, No.10 TH III Jan-Mar.

Wikjonsastro, H. (2005). Dalam Ilmu Kebidanan. Jakarta: Yayasan Bina Pustaka Sarwono Prawirohardjo. 
Yolanda., Taufik., \& Nurfarhanah. (2013).

Hubungan Antara Pengetahuan Tentang

Menarche Dengan Kecemasan Siswi.

Jurnal Ilmiah Konseling, 2(1), 53-58. 